\title{
Biological invasions and ecosystem functioning: time to merge
}

\author{
Ronaldo Sousa $\cdot$ Pedro Morais $\cdot$ Ester Dias • \\ Carlos Antunes
}

Received: 21 September 2010/Accepted: 15 December 2010/Published online: 12 February 2011

(C) Springer Science+Business Media B.V. 2011

Keywords Biodiversity · Biological invasions · Ecosystem functioning - Ecosystem services - World Conference on Biological Invasions and Ecosystem Functioning · BIOLIEF

The movement of species is a key characteristic of our planet. However, in recent decades, humans increased the rate and scale of these movements and are responsible for many introductions of non-indigenous invasive species (NIS) in all types of ecosystems, from the tropics to the poles and from terrestrial to aquatic environments (Carlton and Geller 1993; Mack et al. 2000). Initially, these movements were

R. Sousa $(\square)$

CBMA - Centre of Molecular and Environmental

Biology, Department of Biology, University of Minho,

Campus de Gualtar, 4710-057 Braga, Portugal

e-mail: ronaldo.sousa@ciimar.up.pt

R. Sousa - P. Morais - E. Dias · C. Antunes CIMAR-LA/CIIMAR - Centro Interdisciplinar de Investigação Marinha e Ambiental, Rua dos Bragas 289, 4050-123 Porto, Portugal

P. Morais

ICCE-International Center for Coastal Ecohydrology, Palácio do Capitão-Mor, Horta das Figuras, EN 125, 8005-518 Faro, Portugal

C. Antunes

Aquamuseu do Rio Minho, Parque do Castelinho, 4920-290 Vila Nova de Cerveira, Portugal just between contiguous regions but later the increased transport of goods and people enlarged the scale of these introductions. Given the magnitude of these movements plus social and economic concerns, research programs on NIS have increased enormously recently and attracted great scientific interest (Pyšek et al. 2008; Pejchar and Mooney 2009; Vilà et al. 2010). This theme has been gaining momentum in theoretical and empirical ecology and is an important topic of research with broad implications in biogeography, genetics, and evolution (Sakai et al. 2001; Sax et al. 2007).

Similarly, the discussion about the relationship between biodiversity and ecosystem functioning (BEF) has matured during the last two decades (Chapin et al. 2000; Loreau et al. 2001; Cardinale et al. 2006; Duffy et al. 2007). Few sub-disciplines in ecology have expanded as quickly as BEF, and this research has stimulated the emergence of new theoretical approaches responsible for advances in our understanding of community and ecosystem ecology (Kinzig et al. 2002; Loreau et al. 2002; Naeem et al. 2009). Until the 1990s, and with few exceptions, biodiversity was considered to depend merely on abiotic conditions; however, ecologists subsequently recognized that the properties of ecosystems are also mediated by biodiversity itself (Chapin et al. 1992). Usually, discussions of BEF focus almost exclusively on what happens to ecosystem processes and functions as species richness declines owing to extinctions (Hooper et al. 2005). This discussion is of great 
concern because human activities are reducing biodiversity, which leads to major ecosystem changes, and are also affecting goods and services that are fundamental for humans (Naeem et al. 2009). Indeed, biodiversity is facing dramatic changes that have resulted in loss of species plus reductions in their distribution and abundance, mainly related to anthropogenic impacts such as habitat loss, pollution, climate change and overexploitation of resources (Sala et al. 2000). In addition, the introduction of species is also responsible for dramatic changes in biodiversity that are leading to the homogenization of Earth's biota by breakage of dispersal barriers (McKinney and Lockwood 1999). At the global scale, the introduction of NIS can cause a net reduction of species (e.g., introduction of top predators, parasites and diseases that are responsible for the extinction of native species). However, on a local scale, species addictions can also result in a net increase of species, which is an interesting subject for future research. Therefore, it is of paramount importance that the discussion of BEF also includes cases of biological invasions that substantially affect diversity.

Although discussions of invasive species and ecosystem functioning are rife in the theoretical literature, studies addressing this issue are few. Indeed, only $4 \%$ of all studies published in Biological Invasions from 1999 to 2009 have analyzed the effect of invasive species on ecosystem functioning. Most of these studies were performed in North America (60\%), focusing mainly on terrestrial ecosystems (53\%) (aquatic ecosystems- 23\%, saltmarshes- 15\%) and plants $(70 \%)$ (invertebrates- 20\%, vertebrates- $10 \%$ ). One conclusion resulting from these published studies is that species addictions will affect ecosystem functioning (e.g., productivity, biogeochemical cycles, decomposition) and biotic interactions (e.g. predator prey interactions, introductions of parasites and diseases), with some species also affecting human wellbeing. These effects will contribute to ecosystem functioning in complex ways and obviously will range from almost negligible to dramatic proportions. Given the growing number of NIS introductions, it is imperative to know which species greatly affect BEF in order to plan proper management actions. This situation requires a link between the field of invasion ecology and BEF research. Both disciplines focus, for example, on the consequences resulting from the loss of species, changes to ecosystem functioning, and measuring species traits to predict community and ecosystem-level impacts. However, a key difference is that BEF research is generally based on experiments that do not allow immigration, whereas NIS ecological research relies on open communities (Engelhardt et al. 2009). Anyway, both fields are eager for crossfertilization and the World Conference on Biological Invasions and Ecosystem Functioning (BIOLIEF), held in Porto (Portugal, 27-30 October 2009), brought together more than 300 researchers from 42 countries to discuss the interplay between NIS and ecosystem functioning. This special issue of Biological Invasions presents 14 articles covering a multitude of aquatic (coastal ecosystems- Le Cam and Viard 2011; Queirós et al. 2011; lakes- Goedkoop et al. 2011) and terrestrial ecosystems (agroecosystems- Dosdall et al. 2011; dunes- Rascher et al. 2011; forests- Dassonville et al. 2011; Økland et al. 2011; Maguire et al. 2011; Szlavecz et al. 2011; Rascher et al. 2011; grasslands- Dassonville et al. 2011; Mediterranean ecosystems- Angulo et al. 2011; sub-antartic islands- Lebouvier et al. 2011) and organisms including molluscs (Queirós et al. 2011; Goedkoop et al. 2011; Le Cam and Viard 2011), insects (Angulo et al. 2011; Dosdall et al. 2011; Lebouvier et al. 2011; Økland et al. 2011), oligochaetes (Szlavecz et al. 2011), and plants (Dassonville et al. 2011; Januchowski-Hartley et al. 2011; Maguire et al. 2011; Rascher et al. 2011; Vicente et al. 2011).

In this BIOLIEF special issue, we present five works that investigate species (Angulo et al. 2011; Queirós et al. 2011; Rascher et al. 2011), inter-species interactions (Økland et al. 2011) and community level effects (Szlavecz et al. 2011), or putative effects, on ecosystem functioning. There are also four works that in essence address NIS management: (1) one determines if a specialist insect can, and how it can, control a non-indigenous plant in North America (Maguire et al. 2011); (2) other shows that the zebra mussel influences a lake's nutrient budget and advocates the successive harvesting of cultured mussels to decrease the impact of cultural eutrophication (Goedkoop et al. 2011), and thus indirectly applies one of the principles of ecohydrology, which is to use biota to regulate hydrology and thus transform threats into opportunities (Zalewski et al. 1997); (3) another applies a spatially explicit decision method to identify spatial configurations of actions to achieve objectives related to invasive species, while minimizing management costs and the likelihood of reinvasion of an aquatic 
macrophyte (Januchowski-Hartley et al. 2011); (4) a last one uses a species distribution model to identify suitable areas for rare native species, which are highly susceptible to invasion by a non-indigenous tree at present and under future land-use and climate change scenarios (Vicente et al. 2011). The impact of climate change is also discussed for a sub-Antartic island, namely its interaction with non-indigenous insects and the vulnerability of these terrestrial ecosystems to future colonization in light of the limited gene pools in these islands (Lebouvier et al. 2011). Non-indigenous insects were also studied in Canadian agro-ecosystems, of which the invasion patterns, economic impacts, and ecological effects were highlighted (Dosdall et al. 2011). In the aquatic realm, we present an article suggesting that one non-indigenous marine gastropod facilitates the infection of the surrounding commercially exploited shellfish by a parasitic sponge, although the impact on the gastropod is still limited (Le Cam and Viard 2011). Finally, a review is also presented arguing that it is an exaggeration to claim that most invasions produce ecosystems impacts; however it also claims that it would not be more of an overstatement than the common assertion that very few introduced species have any significant impact (Simberloff 2011).

Future research opportunities on this topic are many, and we challenge our colleagues to diversify the studied ecosystems, to consider more frequently the context-dependent impact of NIS on ecosystem functioning, to analyze the effect of migration in BEF long-term studies, and also to study NIS microorganisms (e.g., viruses, bacteria, protists, microarthropods and nematodes), because they may be key organisms in regulating ecosystem processes and functions. We hope that the first World Conference on Biological Invasions and Ecosystem Functioning and this special issue can contribute to boost the number of works combining invasion ecology and ecosystem functioning, and also can call this important topic to the attention of policy makers, managers, and the general public.

Acknowledgments: We want to thank all the authors and reviewers for their meaningful contributions to this special issue. We are also grateful to Dr Daniel Simberloff for his suggestions and comments on the initial draft of this preface and his guidance during the preparation of this special issue. Finally, we would like to thank Dr João Coimbra, director of
CIIMAR - Centro Interdisciplinar de Investigação Marinha e Ambiental, for the support given during the preparation of the BIOLIEF conference.

\section{References}

Angulo E, Caut S, Cerdá X (2011) Scavenging in Mediterranean ecosystems: effect of the invasive Argentine ant. Biol Invasions 13:1183-1194

Cardinale BJ, Srivastava DS, Duffy JM et al (2006) Effects of biodiversity on the functioning of trophic groups and ecosystems. Nature 443:989-992

Carlton JT, Geller JB (1993) Ecological roulette: the global transport of non-indigenous marine organisms. Science 261:78-83

Chapin FS, Schulze E, Mooney H (1992) Biodiversity and ecosystem processes. Trends Ecol Evol 7:107-108

Chapin FS, Zavaleta ES, Eviner VT et al (2000) Consequences of changing Biodiversity. Nature 405:234-242

Dassonville N, Guillaumaud N, Piola F et al (2011) The niche construction by the invasive Asian knotweeds (species complex Fallopia): impact on activity, abundance and community structure of denitrifiers and nitrifiers. Biol Invasions 13:11151133

Dosdall LM, Cárcamo H, Olfert O et al (2011) Insect invasions of agroecosystems in the western Canadian prairies: case histories, patterns, and implications for ecosystem function. Biol Invasions 13:1135-1149

Duffy JE, Cardinale BJ, France KE et al (2007) The functional role of biodiversity in ecosystems: incorporating trophic complexity. Ecol Lett 10:522-538

Engelhardt K, Symstad A, Prieur-Richard A-H et al (2009) Opening communities to colonization - the impacts of invaders on biodiversity and ecosystem functioning. In: Naeem S, Bunker DE, Hector A et al (eds) Biodiversity, ecosystem functioning and human wellbeing: an ecological and economic perspective. Oxford University Press, New York, pp 217-229

Goedkoop W, Naddafi R, Grandin U (2011) Retention of N and $\mathrm{P}$ by zebra mussels (Dreissena polymorpha Pallas) and its quantitative role in the nutrient budget of eutrophic Lake Ekoln, Sweden. Biol Invasions 13:1077-1086

Hooper DU, Chapin FS III, Ewel JJ et al (2005) Effects of biodiversity on ecosystem functioning: a consensus of current knowledge. Ecol Monograph 75:3-35

Januchowski-Hartley SR, Visconti P, Pressey RL (2011) A systematic approach for prioritizing multiple management actions for invasive species. Biol Invasions 13:1241-1253

Kinzig AN, Pacala SW, Tilman D (2002) The functional consequences of biodiversity. Princeton University Press, New Jersey

Le Cam S, Viard F (2011) Infestation of the invasive mollusc Crepidula fornicata by the native shell-borer Cliona celata: high parasite load without detrimental effects. Biol Invasions 13:1087-1098

Lebouvier M, Laparie M, Hullé M et al (2011) The significance of the sub-Antarctic Kerguelen Islands to assess the 
vulnerability of native communities to climate change, alien insect invasions and plant viruses. Biol Invasions 13:1195-1208

Loreau M, Naeem S, Inchausti P et al (2001) Biodiversity and ecosystem functioning: Current knowledge and future challenges. Science 294:804-808

Loreau M, Naeem S, Inchausti P (2002) Biodiversity and ecosystem functioning: synthesis and perspectives. Oxford University Press, New York

Mack RN, Simberloff D, Lonsdale WM et al (2000) Biotic invasions: causes epidemiology, global consequences and control. Ecol Appl 10:689-710

Maguire D, Sforza R, Smith SM (2011) Impact of herbivory on Vincetoxicum spp. fitness, invasive Apocynaceae species in North America. Biol Invasions 13:1229-1240

McKinney ML, Lockwood JL (1999) Biotic homogenization: a few winners replacing many losers in the next mass extinction. Trends Ecol Evol 14:450-453

Naeem S, Bunker DE, Hector A et al (2009) Biodiversity, ecosystem functioning and human wellbeing: an ecological and economic perspective. Oxford University Press, New York

Økland B, Erbilgin N, Skarpaas O et al (2011) Inter-species interactions and ecosystem effects of non-indigenous invasive and native tree-killing bark beetles. Biol Invasions 13:1151-1164

Pejchar L, Mooney HA (2009) Invasive species, ecosystem services and human well-being. Trends Ecol Evol 24: 497-504

Pyšek P, Richardson DM, Pergl J et al (2008) Geographical and taxonomic biases in invasion ecology. Trends Ecol Evol 23:237-244
Queirós AM, Hiddink JG, Johnson G et al (2011) Context dependence of marine ecosystem engineer invasion impacts on benthic ecosystem functioning. Biol Invasions 13:1059-1075

Rascher KG, Große-Stoltenberg A, Máguas C et al (2011) Acacia longifolia invasion impacts vegetation structure and regeneration dynamics in open dunes and pine forests. Biol Invasions 13:1099-1113

Sakai AK, Allendorf FW, Holt JS et al (2001) The population biology of invasive species. Annu Rev Ecol Syst 32:305-332

Sala OE, Chapin FS, Armesto JJ et al (2000) Global biodiversity scenarios for the year 2100. Science 287:1770-1774

Sax DF, Stachowicz JJ, Brown JH et al (2007) Ecological and evolutionary insights from species invasions. Trends Ecol Evol 22:465-471

Simberloff D (2011) How common are invasion-induced ecosystem impacts? Biol Invasions 13:1255-1268

Szlavecz K, McCormick M, Xia L et al (2011) Ecosystem effects of non-native earthworms in Mid-Atlantic deciduous forests. Biol Invasions 13:1165-1182

Vicente J, Randin CF, Gonçalves J et al (2011) Where will conflicts between alien and rare species occur after climate and land-use change? A test with a novel combined modeling approach. Biol Invasions 13:1209-1227

Vilà M, Basnou C, Pyšek P et al (2010) How well do we understand the impacts of alien species on ecosystem services? A pan-European cross-taxa assessment. Front Ecol Environ 8:135-144

Zalewski M, Janauer GA, Jolánkai G (1997) Ecohydrology - a new paradigm for the sustainable use of aquatic resources. UNESCO, Paris 